\title{
Improving Critical Thinking Skills and Self Efficacy Through Scientific Critical Thinking Model
}

\author{
Rusmansyah \\ Chemistry Education Study Program \\ Lambung Mangkurat University \\ Banjarmasin, Indonesia \\ rusmansyah@ulm.ac.id
}

\author{
Leny Yuanita, Muslimin Ibrahim \\ Science Education Department \\ Surabaya State University \\ Surabaya, Indonesia \\ lennyyuanita@unesa.ac.id \\ musliminibrahim@unesa.ac.id
}

\author{
Isnawati \\ Primary Teacher Education Study Program \\ Lambung Mangkurat University \\ Banjarmasin, Indonesia \\ isnawati53@gamil.com
}

\begin{abstract}
Research has been conducted on the feasibility of the Scientific Critical Thinking (SCT) model to improve critical thinking skills and self efficacy of PGSD students in colloidal material. The syntax of the SCT model is 1) student orientation, 2) scientific activity, 3) presentation of results of scientific activities, 4) completion of critical thinking task, and 5) evaluation. This research is development research to determine the practicality and effectiveness of the prototype SCT model in learning Colloidal material. The study subjects were PGSD students in 2017/2018 with a total of 75 people. The research instrument used was critical thinking adaptation instruments from Facione and self-efficacy adaptation instruments from Users \& Fajares. The results of the study revealed that the feasibility of the SCT model show a very good category $(87.02 \%)$, student activity in learning show a very active category $(85.71 \%)$, there is an increase in critical thinking skills (mean N-gain $=0.86$ / high) and self-efficacy of prospective teacher students is mean $\mathrm{N}$-gain $=0.79 /$ high. Thus, the SCT model has met the requirements of practicality and effectiveness as a prototype of a mode.
\end{abstract}

\section{Keywords—critical thinking skills; self efficacy; SCT model}

\section{INTRODUCTION}

21st-century skills are a basic need in facing the fourth industrial revolution. One of the 21 st-century skills that Primary Teacher Education or Pendidikan Guru Sekolah Dasar (henceforth-PGSD) students must have is critical thinking skill. Critical thinking skill is important for PGSD students. Based on the results of previous research studies, learning and assessment of critical thinking skill are very necessary, and they are driven by the needs of students at the college level and work environment [1][2][3][4][5]. Therefore, educators are required to improve the critical thinking skill of PGSD students in Indonesia.

PGSD students not only have critical thinking skill but also have high self-efficacy to be able to compete in the fourth industrial revolution. The results show that self-efficacy had a direct positive effect on students' scientific attitudes [6][7]. Positive self-efficacy is closely related to motivation, learning behavior, general expectations in the future and student performance [8]. The results of the study show the importance of self-efficacy that must be trained and owned by elementary school candidates in Indonesia. Therefore, an innovative learning model is needed to be able to improve critical thinking skills and self-efficacy of PGSD students.

The Scientific Critical Thinking (SCT) model is a learning model specifically developed from the Problem Based Learning (PBL) model and Inquiry model to train critical thinking skill and self-efficacy of elementary school teacher candidates. The syntax of the SCT learning model developed is 1) Student orientation, 2) Scientific Activities, 3) Presentation of Scientific Activity Results, 4) Completion of Critical Thinking Tasks, and 5) Evaluation. This SCT learning model refers to the John Dewey problem solving process flow [9].

This study is conducted to fulfill the practicality and effectiveness aspects of the SCT learning model. So, it focuses on how the SCT model learning is implemented seen from the results of the students' critical thinking skills and their efficacy. This is done in line with the product criteria (mode) of a learning model that must meet the requirements for validity, practicality, and effectiveness [63].

\section{METHOD}

This study employed a development research design to produce a product and test the effectiveness of a product produced, namely the SCT model to improve critical thinking skills and self efficacy of PGSD students [7]. The research design development used McKenney models with three stages, namely: 1) the preliminary study phase includes needs analysis, literature study, and field surveys, 2) the design phase of the model prototype, validation, revision, and testing, 3) the model testing stage. 
In this paper, the researchers reported the results of the model testing phase, namely the practicality and effectiveness aspects of the SCT learning model. It was done by observing and evaluating the learning activities of the SCT model (model trials) related to the implementation of the Lesson Plan (RPP) and student activities in learning, results of student critical thinking skill and self efficacy.

The research subjects were class F PGSD students with a total of 75 people who programed Science 3 courses. Learning activities took place in 3 lectures face-to-face (@3 x 50 minutes), on the topic of Colloids. Observations and assessments were carried out by two observers using the lecture implementation instrument to obtain data on the ability of lecturers to carry out learning in the SCT model. The practicality of the SCT model is described based on the percentage of SCT model syntax, student activity in learning, the results of students' thinking skills and their self efficacy. This SCT model is said to be practical if the percentage of the implementation of the SCT model phases is not less than 75\% with the criteria of the lecturer's ability to implement the learning model at least Good $(>70 \%)$. Student activities in the SCT model learning activities is at least on active category (> $70 \%)$. The effectiveness of the SCT model is described based on the achievement of the results of students' critical thinking skills with the value of critical thinking skills $=3.0$ and the $\mathrm{N}$ Gain value> 0.3 (medium criteria) and self efficacy with a value of 2.0 (sure criteria) and $\mathrm{N}-$ Gain values $>0.3$ (medium criteria) [10].

\section{RESULTS AND DISCUSSION}

\section{A. The Practicality of the SCT Model}

The Scientific Critical Thinking (SCT) model is a learning model specifically developed from the Problem Based Learning (PBL) model and Inquiry model to train critical thinking skill and PGSD student self-efficacy. The syntax of the SCT learning model developed is 1) student orientation, 2) scientific activities, 3) presentation of scientific activity results, 4) completion of critical thinking tasks, and 5) evaluation. This SCT learning model refers to the John Dewey problem solving process flow [9].

The student orientation phase is supported by the ARCS theory to arouse curiosity and student interest in learning, self efficacy, social constructivist, top-down processes, and the theory of primacy effects [11][9][12][13]. Also, it is supported by several research results such as [8][14][15][16][17][18], which states that motivation can have an effect on individual success and critical thinking and self-efficacy has a positive effect on students' scientific attitudes toward chemistry.

On the scientific activity phase, it is supported by Piaget's cognitive constructivist theory [12], social constructivist theory Vygotsky [13][19][9], which states that students need information relevant to learning, actively involved in the process of information and construction of their knowledge, involved interaction with adults and peers who are more capable, students learn the best concepts in the Zone of Proximal Development (ZPD). This supports the results of [20] and [21] research, which states that varied content is needed in scientific inquiry activities so that students have sufficient provision when becoming chemistry teachers, need to optimize experimental activities that vary in the laboratory and need to improve self efficacy students in science process-based activities in laboratory investigations.

Then, phase 3 is the presentation of scientific activity results. It is supported by the cognitive apprenticeship theory [13], dual coding theory [13], cognitive constructivist theory [13], self efficacy [9], and retention theory [19]. It is stated that a person's beliefs will motivate to be able to do a good job, given the observed behavior in order to emulate it in the future, good information if presented varies, and stimulation of information will be obtained if processed seriously and deeply will be able to obtain good knowledge, skills and attitude. This is supported by the results of research by [22][23], which states that students who are serious in processing information will have better memories, varied methods and models and a good learning environment will support maximizing students' critical thinking skills to the fullest.

Meanwhile, on phase 4 namely completion of critical thinking tasks is supported by theories related to self efficacy, self regulated learning, scaffolding [9][13][19], where selfconfidence, self-regulation independently, positive transfer of past knowledge useful to facilitate learning something or solve new lazah, change the mental representation of students made during coding for motoric activity, and provide assistance as needed to solve problems that are given both complex tasks, difficult and realistic, so that it will improve critical thinking skills and self efficacy college student. This is supported by the results of [2][24][25], which states that the need for systematic, structured learning activities, transfer more roles to students in learning activities so that they will improve critical thinking skills and self its efficacy.

The last, the evaluation phase is supported by theories related to self efficacy, self evaluation, recency effects, contingent praise, cognition, and motivation [9][13][19] where evaluation is useful to assess what has been done as a reflection for further improvement and motivated to be even better. According to [12] the evaluation of lecturers from the investigation process conducted by students is a peer component in the context of critical thinking processes.

The practicality of the SCT model can be obtained from the learning implementation data provided by the observer on the ability of the lecturer to carry out lectures and student activities during learning.

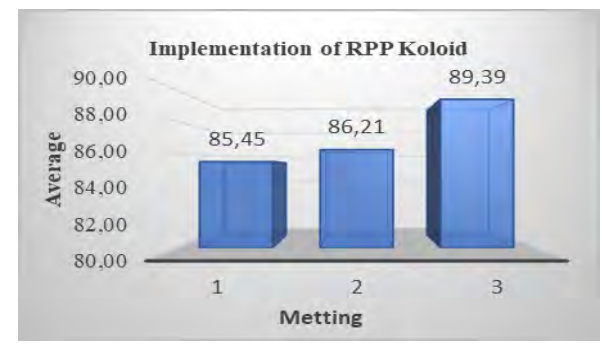

Fig. 1. Implementation of the SCT model

Fig. 1 shows that the implementation of the RPP in the three meetings for Colloidal material with phases of the SCT 
model syntax can be carried out entirely by the lecturer, meeting $1=85.45 \%$ (Very Good), meeting $2=86.21 \%$ (Very Good), meeting $3=89.39 \%$ (Very Good). The average rating given by the observer to the lecturers' ability for 3 meetings showed a positive result, which was $87.02 \%$ (Very Good category). The quality of teaching lecturers is increasing from meeting 1 to meeting 3 . This is because lecturers increasingly master the phases of the SCT model learning model well. Increasing the ability of lecturers in applying the SCT model in Colloidal learning along with the input and suggestions were given by observers during learning activities so that lecturers can improve the learning process well.

The syntax phases of the SCT model carried out by the lecturer can be seen in Figure 2.

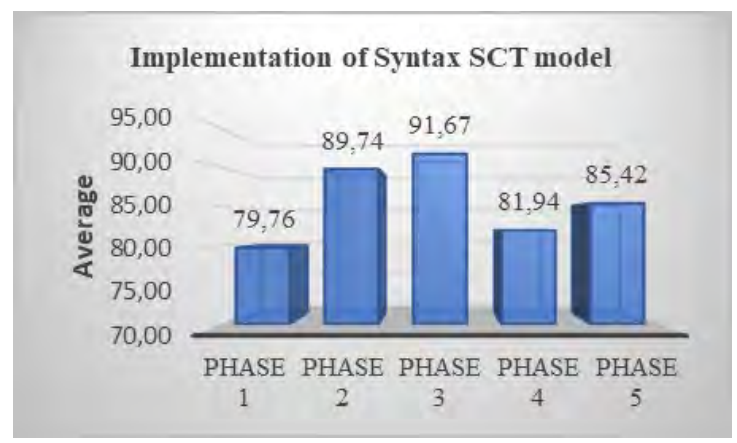

Fig. 2. Implementation of SCT model syntax

Figure 2 shows the learning phases of the SCT model have been carried out entirely by the lecturer well. Quality of Phase 1 implementation Student orientation 79.76\% (Very Good), Phase 2 Scientific Activity 89.74\% (Very Good), Phase 3 Presentation of Scientific Activity results is $91.67 \%$ (Very Good), Phase 4 Completion of Critical Thinking Tasks 81, 94\% (Very Good), and Phase 5 Evaluation $85.42 \%$ (Very Good). All learning phases of the SCT model have been carried out by lecturers (above 75\%) with the quality of lecturers in the teaching of the Very Good category (above 70\%). Thus the practicality of the SCT model has met the criteria of a prototype learning model.

Student activities in learning with the SCT model are shown in Figure 3.

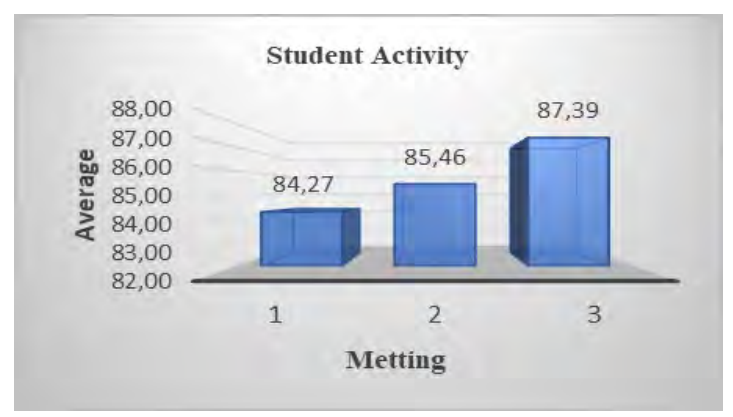

Fig. 3. Student activities

Figure 3 shows that student activities at the three meetings for Colloidal material with phases of the SCT model syntax can be carried out entirely by lecturers, meeting $1=84.27 \%$ (Very Active), meeting $2=85.46 \%$ (Very Active), meeting $3=$
87.39\% (Very Active). The average rating given by the observer to the lecturers' ability for 3 meetings showed a positive result, which was $85.71 \%$ (Very Active). Student activities increased from meeting 1 to meeting 3, this was due to lecturer guidance during the learning process of the SCT model very well. Students are fully involved by lecturers from the beginning of learning to the end of learning so that their activities in the learning process are high, both for individual tasks, group assignments, and practicum activities.

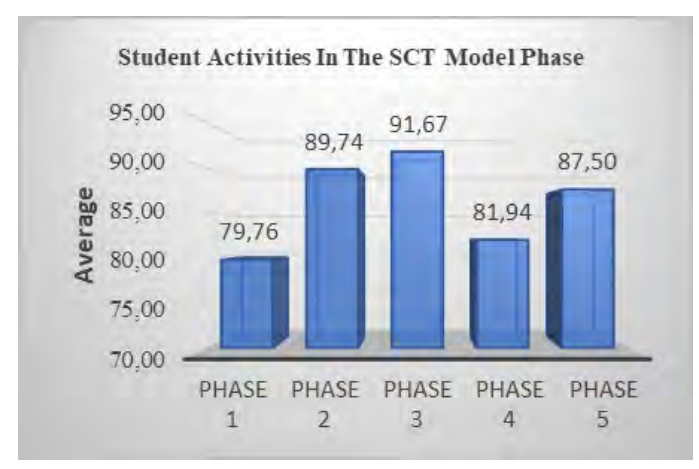

Fig. 4. Student activities in the SCT model

Figure 4 shows that student activities in learning activities with the SCT model include very active categories. Each learning phase shows positive student activity. Percentage of student activity in learning activities in Phase 1 Student orientation $79.76 \%$ (Very Active), Phase 2 Scientific Activity $89.74 \%$ (Very Active), Phase 3 Presentation of Scientific Activity Results $91.67 \%$ (Very Active), Phase 4 Critical Thinking Task Completion 81.94\% (Very Active), and Evaluation Phase $587.50 \%$ (Very Active). The average student activity in the learning process of the SCT model was $86.12 \%$ (Very Active). The activity of students is because in each phase of learning students are always involved.

Thus, the feasibility of the SCT model, the ability of lecturers to carry out the phases of the SCT model and student activities in the learning activities of the SCT model indicate that the SCT learning model meets the requirements of a learning model in terms of practicality.

\section{B. The effectiveness of the SCT Model}

The effectiveness of the SCT model is described based on the completeness of students' critical thinking skills and their self efficacy. At the time of the pretest, all students were not complete in solving the questions of critical thinking skills. The achievement of critical thinking indicators is still below 3.0. Indicator achievement analysis $=1.51$ (low), evaluation indicator $=1.63$ (low), interpretation indicator $=1.29$ (low), and inference indicator $=1.37$ (low). After learning with the SCT model, then the posttest was done to increase students' critical thinking skills, where the indicator of analysis $=3.77$ (high), evaluation indicators $=3.74$ (high), interpretation indicators $=3.60$ (high) and inference indicators $=3.66$ (high). Thus all students complete in solving the questions of critical thinking skills given. 


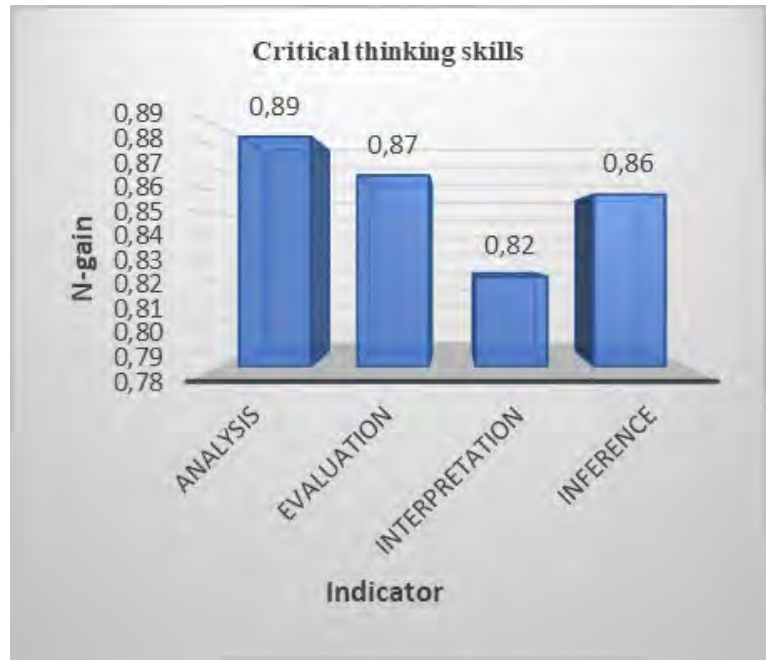

Fig. 5. Student critical thinking skills

Figure 5 shows that students' critical thinking skills during learning with the SCT learning model show positive results with $\mathrm{N}$-Gain values for all critical thinking indicators above 0.3 . The value of the $\mathrm{N}-$ Gain indicator analysis $=0.89$ (high), evaluation indicators $=0.87$ (high), interpretation indicators $=$ 0.82 (high) and inference indicators $=0.86$ (high). These results indicate that students' critical thinking skills in learning Colloidal material using the SCT model are complete. Increasing students' critical thinking skills in completing test questions is caused by students having been trained in critical thinking skills in the phases of the SCT model, especially in the scientific activity phase, the presentation phase of scientific activity results and the phase of completion of critical thinking tasks.

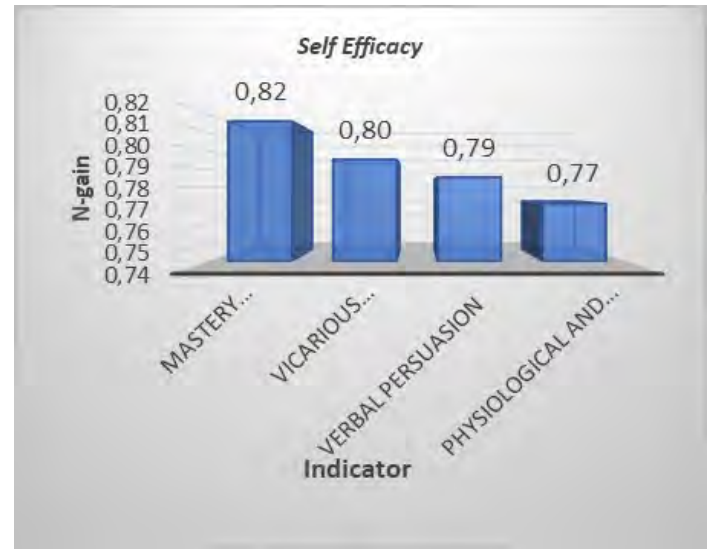

Fig. 6. Student self-efficacy

Figure 6 shows the student's self efficacy during learning with the SCT model. Before the student's self efficacy learning activities were still relatively low, the average mastery experiences indicator was 1.19 (pretty sure), vicarious experiences $=1.19$ (quite sure), verbal persuasion $=1.20$ (sure enough), and physiological and affective states $=1.21$ (sure enough). After the implementation of learning with the SCT model, there was an increase in student self-efficacy, the average mastery experiences indicator $=3.48$ (very confident), vicarious experiences $=3.43$ (very confident), verbal persuasion $=3.40$ (very confident), and physiological and affective states $=3.36$ (very sure) $\mathrm{N}$-gain mastery experiences indicator $=0.82$ (very high), vicarious experiences $=0.80$ (very high), verbal persuasion $=0.79$ (very high), and physiological and affective states $=0.77$ (very high). The increase in selfefficacy of students is inseparable from the design of each phase of the SCT learning model always training 4 selfefficacy indicators in their learning activities so that students have increased confidence in completing tasks given by lecturers during the learning process.

Thus, concerning the completeness of critical thinking skills and self efficacy of prospective chemistry teachers, the SCT model can be said to be effective.

\section{CONCLUSION}

The SCT model is one of the learning models that can improve the student critical thinking skill and self efficacy of ULM PGSD students. The syntax of the SCT learning model developed is 1) student orientation; 2) scientific activities; 3) presentation of scientific activity results; 4) completion of critical thinking tasks; 5) evaluation. The practicality of the SCT model as evidenced by the implementation of Colloidal RPP in accordance with the syntax of the SCT model conducted by the lecturer showed very good results and the activity of students in Colloidal learning with the SCT model was very active. The effectiveness of the SCT model is shown by the increase of students' critical thinking skills and the increase in student self-efficacy in completing the tasks given by the lecturer.

\section{REFERENCES}

[1] A. M. S. Atabaki, N. Keshtiaray, and M. H. Yarmohammadian, "Scrutiny of Critical Thinking Concept," Int. Educ. Stud., vol. 8, no. 3, pp. 93-102, 2015.

[2] B. Birgili, "Creative and Critical Thinking Skills in Problem-based Learning Environments,” J. Gift. Educ. Creat., vol. 2, no. 2, pp. 71-73, 2015 .

[3] C. Kivunja, "Using de Bono's Six Thinking Hats Model to Teach Critical Thinking and Problem Solving Skills Essential for Success in The 21st Century Economy," Creat. Educ., vol. 6, no. 03, pp. 380-391, 2015.

[4] F. Kalelioğlu and Y. Gülbahar, "The effect of instructional techniques on critical thinking and critical thinking dispositions in online discussion," Educ. Technol. Soc., vol. 17, no. 1, pp. 248-258, 2014.

[5] G. Sirhan, "Learning difficulties in chemistry: an overview.," Turkish Sci. Educ., vol. 4, no. 2, 2007.

[6] N. I. Kurbanoglu and A. Akim, "The Relationships Between University Students' Chemistry laboratory Anxiety, Attitudes, and Self-efficacy Beliefs,” Aust. J. Teach. Educ., vol. 35, no. 8, pp. 48-59, 2010.

[7] Peraturan Presiden, Presidential Regulation of the Republic of Indonesia Number 8 of 2012 Concerning the Indonesian National Qualifications Framework. Peraturan Presiden, 2012.

[8] OECD, PISA 2015 Collaborative Problem Solving Framework. Washington: OECD Publishing, 2013.

[9] R. Moreno, Educational psychology. New York: Pearson Education Inc., 2010.

[10] R. R. Hake, “Analyzing Change/Gain Score,” Am. Educ. Assoc. Div. D, Meas. Res. Methodol., 1999. 
[11] M. J. Keller, Motivational Design for Learning and Performance The ARCS Model Approach. USA: Springer, 2010.

[12] R. I. Arends, Learning to Teach, 9th ed. New York: Mc. Graw -Hill Companies, Inc, 2012.

[13] E. R. Slavin, Educational psychology: Theory and Practice. Boston: Pearson, 2011.

[14] S. J. O'Neill, M. B., S. N.r, and S. A. D., "On the Use Imagery for Climate Change Engagement," J. Glob. Environ. Chang., vol. 23, pp. 413-421, 2013.

[15] E. A. Gomez, W. Dezhi, and P. Katia, “Computer- supported Team-Base Learning: The Impact of Motivation, Enjoyment and Team Contributions on Learning Outcomes," J. Comput. Educ., vol. 55, pp. 378-390, 2010.

[16] S. Järvelä, S. Volet, and H. Järvenoja., "Research on Motivation in Collaborative Learning: Moving Beyond the Cognitive-situative Divide and Combining Individual and Social Processes," J. Educ. Psychol., vol. 45, pp. 15-27, 2010.

[17] F. P. Morgeson, M. H. R., and M. A. C., "Selecting Individuals in Team Settings: The Importance of Social Skills, Personality Characteristics, and Teamwork Knowledge," J. Pers. Psychol., vol. 58, pp. 583-611, 2005.

[18] A. Klegeris, M. Bahniwal, and H. Hurren, "Improvement in Generic Problem-solving Abilities of Students by Use of Tutor-less Problem- based Pearning in a Large Classroom Setting," CBE-Life Sci. Educ., vol. 12, pp. 73-79, 2013.

[19] A. Bandura, "Self-efficacy: Toward Unifying Theory of Behavioral Change," Psychol. Rev., vol. 84, no. 2, pp. 191-215, 1977.

[20] F. Alkan, "Experiential Learning: Its Effects on Achievement and Scientific Process Skills," J. Turkish Sci. Educ., vol. 13, no. 2, pp. 1526, 2016.

[21] H. S. Scott, "Inquiry, Efficacy, and Science Education," Electronic Theses \& Dissertations. Disertation: Georgia Southern University, 2013.

[22] Q. Zhou, Q. Huang, and Q. Tian, "Developing Students' Critical Thinking Skills by Task-Based Learning in Chemistry Experiment Teaching," Creat. Educ., vol. 4, no. 12, pp. 40-45, 2013.

[23] V. Batdi, "The Effects of Problem Based Learning Approach on Students' Attitude Levels: A Meta-analysis,” Educ. Res. Rev., vol. 9, no. 9, pp. 272-276, 2014.

[24] S. K. Sasser, "Effect of Structure in Problem Based Learning on Science Teaching Efficacy Beliefs and Science Content Knowledge of Elementary Preservice Teachers," Dissertation Southern Illinois University Carbondale, 2014.

[25] L. M. Mataka and M. G. Kowalske, "The influence of PBL on Students' Self-efficacy Beliefs in Chemistry," Chem. Educ. Res. Pr., vol. 16, pp. 929-938, 2015. 